\title{
Biological response to iron fertilization in the eastern equatorial Pacific (IronEx II). I. Microplankton community abundances and biomass
}

\author{
M. R. Landry ${ }^{1, *}$, M. E. Ondrusek ${ }^{2}$, S. J. Tanner ${ }^{3,}$ S. L. Brown ${ }^{1}$, J. Constantinou ${ }^{1}$, \\ R. R. Bidigare ${ }^{1,4}$, K. H. Coale ${ }^{3}$, S. Fitzwater ${ }^{5}$ \\ ${ }^{1}$ Department of Oceanography, University of Hawai'i at Manoa, Honolulu, Hawai'i 96822, USA \\ ${ }^{2}$ DOC/NOAA/NESDIS, E/RA30, 5200 Auth Rd. Camp Springs, Maryland 20746, USA \\ ${ }^{3}$ Moss Landing Marine Laboratories, PO Box 450, Moss Landing, California 96039, USA \\ ${ }^{4}$ Hawai'i Institute of Marine Biology, PO Box 1346, Kaneohe, Hawai'i 96744, USA \\ ${ }^{5}$ MBARI, PO Box 628, Moss Landing, California 95039, USA
}

\begin{abstract}
During the IronEx II experiment in the eastern equatorial Pacific (May to June 1995), the response of the microplankton community to mesoscale iron fertilization was followed using a combination of marker-pigment, microscopical and flow cytometric techniques. Phytoplankton standing stock bloomed dramatically over a period of $6 \mathrm{~d}$ following 3 iron additions of 2 and $1 \mathrm{nM}$, respectively. Carbon biomass in the patch increased by a factor of 4, chlorophyll a by about a factor of 16 and diatoms by $>70$-fold relative to contemporaneous levels in the ambient community. The bloom then plateaued sharply and remained at a more or less constant level for $4 \mathrm{~d}$, despite the addition of more iron (1 nM) and physiological indices (low C:chl a ratio and elevated photochemical quantum efficiency) suggesting that the cells were healthy and growing rapidly. Relatively large pennate diatoms (Nitzschia spp., median length 20 to $24 \mu \mathrm{m}$ ) dominated the patch bloom, with smaller pennate species and centric diatoms declining in relative importance. Heterotrophic bacteria increased at a slow rate $\left(0.08 \mathrm{~d}^{-1}\right)$ for $>10 \mathrm{~d}$ during the experiment, as did heterotrophic nanoflagellates. There were also indications of enhanced cell size, cellular pigment content and possibly growth rates of small phytoplankton. Nonetheless, little difference was observed between the ambient community and the peak patch bloom with respect to the size composition of auto- and heterotrophic populations $<10 \mu \mathrm{m}$ in cell size. The relative constancy of the smaller size fractions, the sharp curtailment of net growth of the bloom after $6 \mathrm{~d}$, and $>3$-fold increase in large heterotrophic dinoflagellates and ciliates suggest that protistan grazers may have played an active role in controlling the phytoplankton response to increased iron availability.
\end{abstract}

KEY WORDS: Diatom · Bloom · Phytoplankton pigments · Carbon:chlorophyll · Size structure · Heterotrophic protists

Resale or republication not permitted without written consent of the publisher

\section{INTRODUCTION}

The eastern equatorial Pacific is one of 3 major oceanic ecosystems, including the subarctic Pacific and Antarctic circumpolar waters, in which the inability of phytoplankton to fully utilize high ambient levels of macronutrients is believed to be due to iron limitation (Martin 1990, Martin et al. 1991). Consistently high concentrations of macronutrients, low levels of

*E-mail: landry@soest.hawaii.edu phytoplankton chlorophyll, and dominance by autotrophic pico- and nanoplankton are common characteristics of these HNLC (high-nutrient, low-chlorophyll) systems. Initially, the case for iron limitation rested on observations of iron-stimulated chlorophyll increase and nutrient utilization in bottle experiments. Interpretations of these experiments were controversial, however, because bottles excluded important components and processes of the natural system (e.g. large zooplankton, sinking and mixing) and because the responses occurred only after several days of con- 
tainment with dramatic shifts in community composition to otherwise rare organisms (e.g. Banse 1990, Cullen 1991). Interpretations were further confounded by the fact that phytoplankton growth and nutrient uptake also occurred in 'control' bottles without (intentional) iron additions.

The first mesoscale iron-enrichment experiment, IronEx I (October 1993), was a major step in taking the iron hypothesis from discussions of bottle artifacts to unequivocal effects on natural ecosystems. It demonstrated the feasibility of fertilizing a patch of the ocean with a micronutrient, of marking the patch with an inert gaseous tracer $\left(\mathrm{SF}_{6}\right)$, and of tracking and resampling the patch in time. It also documented significant enhancements in physiological condition, biomass, and productivity of phytoplankton in the enriched patch, thus providing strong supporting evidence for the hypothesis that waters of the equatorial Pacific were iron-limited (Greene et al. 1994, Kolber et al. 1994, Martin et al. 1994). Despite these achievements, many questions remained unresolved by this experiment; in particular, the responses of the system in terms of chlorophyll growth, nutrient utilization and inorganic carbon drawdown were not as dramatic as expected (Martin et al. 1994, Watson et al. 1994). In addition, the patch was prematurely subducted under more buoyant waters, and the potential roles of grazers in modulating the phytoplankton iron response were not addressed (Banse 1995, Cullen 1995).

The IronEx II experiment (May to June, 1995) was designed to be a longer and more detailed investigation of geochemical, physiological, and ecological responses to iron enrichment. The massive phytoplankton bloom that resulted provided dramatic and unqualified proof of iron limitation in the equatorial Pacific (Coale et al. 1996), and its success has been the basis for the planning and implementation of similar experiments in other HNLC regions. Although the geochemical results and implications of the IronEx II study have been presented in some detail (e.g. Coale et al. 1996, Cooper et al. 1996, Turner et al. 1996, Bidigare et al. 1999), information on the biological responses has been sparse and in some cases anecdotal. The goal of the present paper is to provide an integrated, quantitative overview of the microplankton community response to iron fertilization from complementary assessments of phytoplankton pigments, flow cytometric and microscopically based population abundances, carbon estimates and community size structure. In the 2 companion papers in this issue, we describe the population and community responses of mesozooplankton (Rollwagen Bollens \& Landry 2000, in this issue) and taxa-specific rates of phytoplankton growth and microzooplankton grazing (Landry et al. 2000, in this issue).

\section{MATERIALS AND METHODS}

Experimental design and sampling. The basic designs of the mesoscale iron-enrichment experiments in the eastern equatorial Pacific have been described in detail elsewhere (Martin et al. 1994, Coale et al. 1996). Briefly, the main IronEx II experiment (May to June, 1995) began at about $4^{\circ} 40^{\prime} \mathrm{S}, 105^{\circ} \mathrm{W}$ with the infusion of $72 \mathrm{~km}^{2}$ of ocean sea surface with a constant ratio mixture of $\mathrm{FeSO}_{4}(\mathrm{pH} 2)$ and the inert tracer $\mathrm{SF}_{6}$. A total of $225 \mathrm{~kg}$ of iron was added to the area as the ship steamed through a rectangular grid pattern, giving an initial mixed-layer concentration of about $2 \mathrm{nM}$. This initial fertilization took place between 10:00 h (GMT) on 29 May and $04: 00 \mathrm{~h}$ on 30 May, the midpoint (19:00 h, Julian Day [JD] 149) being the nominal starting point $(t=0)$ of the experiment. Two additional iron infusions of about $1 \mathrm{nM}$ each were conducted from 15:00 h to 24:00 h on JD 152 (Day 3) and from 18:00 h on JD 157 to 01:00 h on JD 158 (Day 7).

To facilitate navigation for the iron infusions and as a point of reference for repeated sampling of the ironenriched 'patch', the center of the patch was marked with an instrumented buoy drogued at $15 \mathrm{~m}$ depth. A second buoy marked the location of a 'control' site with no iron addition. As indicated by Coale et al. (1996), the patch buoy drifted at an average speed of $2.8 \mathrm{~km}$ $\mathrm{h}^{-1}$ throughout the experiment, ending up $1500 \mathrm{~km}$ south-southwest of its initial position after $19 \mathrm{~d}$.

Distributions of seawater properties related to the patch development (e.g. phytoplankton pigments, $\mathrm{SF}_{6}$, iron, $\mathrm{NO}_{3}$ and $\mathrm{pCO}_{2}$ ) were mapped approximately daily from JDs 151 to 159 during nighttime grid surveys using water collected at $6 \mathrm{~m}$ depth from the ship's PVC pumping system. This strategy was used to follow the patch through time and to locate the area of strongest patch response relative to the marker buoy for more detailed sampling and experimental work each day. In the present study, discrete seawater samples for population pigment and microscopical analyses were collected in the central region of the patch and near the control buoy using a CTD rosette with 301 Go-Flo bottles.

HPLC pigment analyses. Seawater samples (2.05 l) for pigment analyses were positive-pressure filtered (<0.3 bar) through $25 \mathrm{~mm}$ Whatman GF/F glass fiber filters. Size-fractioned pigment samples were prepared by passing 2.051 samples through a series of $25 \mathrm{~mm}$ Gelman in-line filter holders containing Poretics polycarbonate membrane filters of decreasing porosity (18, 10, 5 and 2 and $0.8 \mu \mathrm{m}$ ), followed by a GF/F filter for the smallest fraction. The filters were wrapped in aluminum foil, immediately frozen in liquid nitrogen and subsequently stored at $-85^{\circ} \mathrm{C}$ until analysis. Filters were sonicated $\left(0^{\circ} \mathrm{C}\right.$, dark) in $3 \mathrm{ml}$ of $100 \%$ acetone 
with $50 \mu \mathrm{l}$ of canthaxanthin in acetone added as an internal standard and extracted in the dark at $-20^{\circ} \mathrm{C}$ for $24 \mathrm{~h}$. Prior to analysis, pigment extracts were vortexed and centrifuged to remove cellular debris.

Subsamples of $200 \mu \mathrm{l}$ of a mixture of $1.0 \mathrm{ml}$ pigment extract plus $0.3 \mathrm{ml} \mathrm{H}_{2} \mathrm{O}$ were injected into a SpectraPhysics SP8800 HPLC system equipped with autosampler, autosampler cooler $\left(4^{\circ} \mathrm{C}\right)$, Dynamax $3 \mu \mathrm{m}$ C-8 analytical and guard columns, and a Waters 440 absorbance (436 nm) detector. Separations followed the binary solvent protocol described by Goericke \& Repeta (1993). Peak identifications were made by comparing the retention times of eluting peaks with those of pure standards and cultured organisms with known pigment composition (Latasa et al. 1996).

HPLC analysis provided concentration estimates for chlorophyll a (chl a) as well as group-specific accessory marker pigments such as divinyl chl a (prochlorophytes), peridinin (dinoflagellates), 19'-butanoyloxyfucoxanthin (pelagophytes and prymnesiophytes), fucoxanthin (diatoms, pelagophytes and prymnesiophytes), 19'-hexanoyloxyfucoxanthin (prymnesiophytes), prasinoxanthin (prasinophytes), and zeaxanthin (cyanobacteria and prochlorophytes). These basic pigment data were used to determine the contributions of the different phytoplankton groups to total chl a using the CHEMTAX program developed by Mackey et al. (1996, 1997).

Population abundances and biomass. All samples for enumeration of plankton population abundances were taken from the middle of the mixed layer at $15 \mathrm{~m}$ depth, typically in the morning after nighttime convective mixing. Samples $(3 \mathrm{ml})$ for analyses of bacteria and pico-phytoplankton were preserved with $0.9 \%$ paraformaldehyde (final concentration), frozen in liquid nitrogen and stored at $-85^{\circ} \mathrm{C}$ until analysis (Vaulot et al. 1989). Frozen samples were thawed and stained in the dark with Hoechst $33342\left(1 \mu \mathrm{g} \mathrm{ml}^{-1}\right)$ for $1 \mathrm{~h}$ (Monger \& Landry 1993), and subsamples of $100 \mu l$ were enumerated with a Coulter EPICS 753 flow cytometer equipped with dual 5W argon lasers, MSDS II automatic sampling, a Biosense flow cell and CICERO Cytomation software. Standard beads $(0.57$ and $0.98 \mu \mathrm{m}$ YG Fluoresbrite microspheres for visible excitation and $0.46 \mu \mathrm{m}$ UV-excitable beads, Polysciences) were added to each sample as a basis for normalizing fluorescence signals. The dual lasers were aligned co-linearly with the first tuned to the UV range at $200 \mathrm{~mW}$ to excite Hoechst-stained DNA. The second was tuned to $488 \mathrm{~nm}$ at $1.3 \mathrm{~W}$ to excite the pigment molecules of autotrophic cells (Landry et al. 1996). Forward angle light scatter (FALS), right angle light scatter (RALS) and 4 fluorescence signals were collected for each cell, stored in list mode files, and analyzed using CYTOPC software (Vaulot 1989). Populations of heterotrophic bacteria (HBACT), Prochlorococcus (PRO), Synecho- coccus (SYN) and pico-eukaryotic cells (PEUK) were distinguished by characteristic autofluorescence, size (RALS) and presence of DNA. SYN were identified principally from their orange fluorescence (575 \pm $40 \mathrm{~nm}$; phycoerythrin), but they were also separate from other populations in scatter plots of red (680 \pm $40 \mathrm{~nm}$; chl a) versus blue (450 $\pm 40 \mathrm{~nm}$; DNA) fluorescence. Among cells of smaller size, PRO were distinguished from HBACT by the presence of red autofluorescence. Eukaryotic algae had substantially larger RALS signals (a function of size and refractive index) and red chlorophyll florescence compared to PRO. Enumerations were corrected for volume analyzed and counting efficiency as a function of cell density using E. coli cells enumerated with an Elzone/Cellscope 80XY particle analyzer.

Samples $(20$ to $50 \mathrm{ml}$ ) for analyses of phytoplankton and heterotrophic nanoplankton were preserved with gluteraldehyde (1\%), concentrated on $0.2 \mu \mathrm{m}, 25 \mathrm{~nm}$ black polycarbonate membrane filters, and stained with DAPI $\left(5 \mu \mathrm{g} \mathrm{ml}^{-1}\right)$ for 3 to $4 \mathrm{~min}$ in the final stages of filtration. The filters were mounted on glass slides with immersion oil and frozen at $-20^{\circ} \mathrm{C}$ prior to analysis. At least 2000 cells were enumerated at 400 to $1000 \times$ magnification for each slide using a Zeiss or Olympus BH2 epifluorescence microscope. Biovolumes were computed for each enumerated group from the closest geometric shape, the 2 visible (length and width) dimensions of the cells on the filter and the estimated third dimension according to Chavez et al. (1991).

Samples $(250 \mathrm{ml})$ for analyses of ciliated protists and $>20 \mu \mathrm{m}$ dinoflagellates were preserved with $5 \%$ acid Lugol's fixative and stored in the dark. Subsamples of $100 \mathrm{ml}$ were settled $48 \mathrm{~h}$ in Utermöhl chambers, and all of the cells in the sample were counted at $400 \times$ using a Zeiss inverted microscope. Biomass estimates and size distributions are based on the measurement of at least 50 cells from each sample. Total abundance and biomass of $>20 \mu \mathrm{m}$ dinoflagellates from Lugol's preserved samples were divided into autotrophic and heterotrophic categories based on the percentages of pigmented and nonpigmented cells in the same size fraction in gluteraldehyde-preserved samples analyzed by epifluorescence microscopy.

Cellular carbon contents of diatoms were estimated from biovolumes following Strathmann (1967), with a $0.54 \times$ correction factor as suggested by Silver \& Gowing (1991) and Chavez et al. (1991). This correction accounts for the volumes of the diatom frustrules and internal vacuoles, which are relatively large with respect to total measured volumes of the slender pennate diatoms that dominated the phytoplankton assemblage. Predicted cellular carbon content from these calculations agreed closely with measured carbon for a culture of Pseudonitzschia sp. with comparable 
dimensions to equatorial Pacific dominants (S. Tanner pers. obs.).

For consistency with previous Joint Global Ocean Flux Study (JGOFS) work in the equatorial Pacific (Verity et al. 1996), we used comparable carbon con-

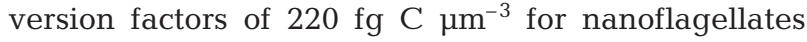

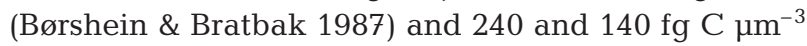
for $<20 \mu \mathrm{m}$ and $>20 \mu \mathrm{m}$ dinoflagellates (Verity et al. 1992 and Lessard 1991, respectively). On average, the biomass estimates using these factors were slightly higher $4 \%$ higher for nanoflagellates and $18 \%$ higher for dinoflagellates) than those from the uncorrected Strathmann (1967) equations. Ciliate biovolumes were converted to carbon equivalents using a mean factor

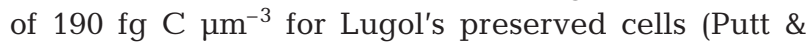
Stoecker 1989).

Comparable cell abundances of PEUKs were observed in flow cytometric and microscopical analyses; therefore, abundance estimates from both techniques were converted to carbon using the mean microscopical size measurement and the nanoflagellate conversion factor $\left(2 \mu \mathrm{m}\right.$ cell diameter, $\left.920 \mathrm{fg} \mathrm{C} \mathrm{cell}^{-1}\right)$. PRO and SYN were both observed to increase in cellular biovolumes by about $50 \%$ during the IronEx II enrichment (Cavender-Bares et al. 1999). To account for these changes, we used carbon estimates of 32 and $101 \mathrm{fg} C$ cell $^{-1}$, respectively, for PRO and SYN cells in the ambient community (Shalapyonok et al. in press), increasing both by $50 \%$ (48 and $152 \mathrm{fg} \mathrm{C} \mathrm{Cell}^{-1}$ ) following the temporal pattern described by Cavender-Bares et al. (1999) (i.e., highest biovolumes occurred from Days 3 to 6). Given large uncertainties in bacterial carbon conversions and unmeasured cell biovolumes in the present experiment, we report only HBACT abundances.

\section{RESULTS}

\section{Pigment distributions}

Phytoplankton pigment responses to the ironenriched patch were evident in mapping surveys beginning $1 \mathrm{~d}$ after the initial fertilization. Monovinyl chl a (MV chl a), the major chlorophyll molecule in all phytoplankton except $\mathrm{PRO}$, was enriched $>2$-fold over ambient concentrations (100 ng $\mathrm{l}^{-1}$ ) on JD 151, and it doubled again on JD 152 (Fig. 1). MV chl a also increased by approximately another factor of 2 between JDs 152 and 154, the day following the second iron-enrichment, and reached a maximum subsurface concentration of about $16 \times$ ambient levels following the third enrichment. The patch was abandoned to pursue other experimental work after MV chl a had begun to decline on JD 159. Subsequent efforts to relocate the patch on JDs 163 and 166 identified waters with enhanced fluorometic chl $a$ and depleted concentrations of nitrate and $\mathrm{CO}_{2}$ to the south of the central buoy (see Fig. 2 in Coale et al. 1996), but these distributions were not clearly resolved with the reduced number of samples analyzed for HPLC pigments.

Overall, the patch slipped relative to the central marker buoy such that a plume of enhanced phytoplankton pigments extended to the south and west as the waters around the buoy were periodically re-fertilized with iron (Fig. 1). Water-column sampling in the central region of the patch also revealed that the depth distribution of pigment enhanced water expanded as the mixed-layer deepened from 25 to $50 \mathrm{~m}$ (Fig. 2). During the peak of the phytoplankton bloom on JDs 157 to 158 , the maximum MV chl a concentration was at about $20 \mathrm{~m}$.

Algal marker pigments showed different responses to the iron-enrichment. For example, fucoxanthin (FUCO), the dominant accessory pigment in diatoms, was initially present in low concentrations but responded rapidly and ultimately dominated the observed distribution patterns in MV chl a (Figs. 1 \& 2). In contrast, 19'hexanoyloxyfucoxanthin (19'-HEX), a diagnostic pigment for prymnesiophytes and the dominant accessory pigment in the ambient seawater, responded rapidly at first, from $<40$ to $>200 \mathrm{ng} \mathrm{l}^{-1}$, but subsequently declined to a lower level $\left(\sim 140 \mathrm{ng} \mathrm{l}^{-1}\right)$ after JD 153. 19'-butanoyloxyfucoxanthin (19'-BUT), a major pigment in pelagophytes, increased gradually to about 4 times ambient concentrations by JD 158 (Fig. 2). Divinyl chl a (DV chl a), found only in PRO, showed no consistent pattern in enrichment relative to background concentrations (not shown). However, the accessory pigment zeaxanthin (ZEAX), present in both PRO and SYN, showed declining concentrations in the patch as the bloom of eukaryotic phytoplankton reached its peak (Fig. 2).

CHEMTAX analysis of the phytoplankton pigments from the patch surface maps suggested that most of the response in community chl a was attributable to prymnesiophytes initially, but ultimately to diatoms as the bloom developed (Fig. 3). By JD 158, the chl a associated with diatoms had increased by more than 2 orders of magnitude above initial concentrations. Other phytoplankton groups, pelagophytes, dinoflagellates and prasinophytes, increased by $\geq 5 \times$ during the same period, each accounting for as much or more of total phytoplankton chl a as PRO by the peak of the patch bloom (Fig. 3).

\section{Phytoplankton abundance and biomass}

As noted above, the phytoplankton bloom response was marked by a 16 -fold increase in MV chl a over the 5 d period from JDs 150 to 155 (Fig. 4). The corre- 

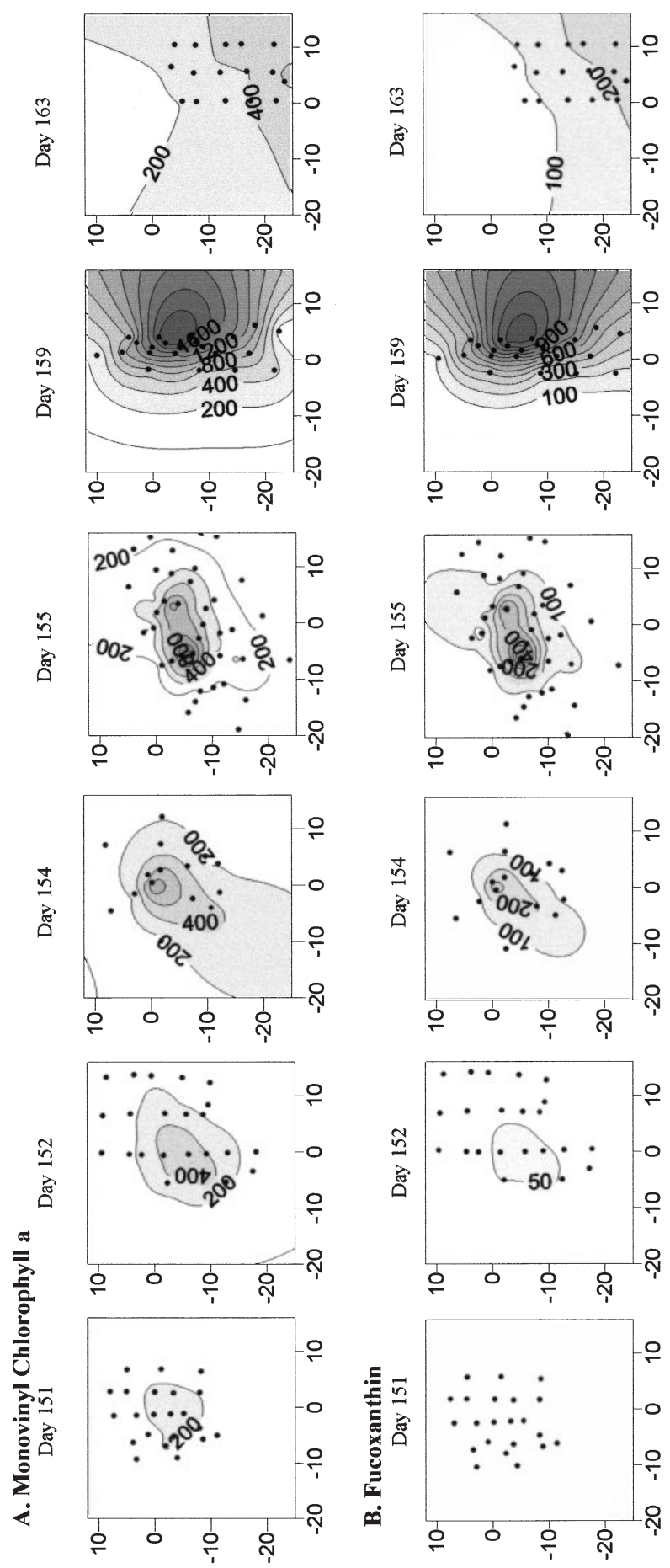
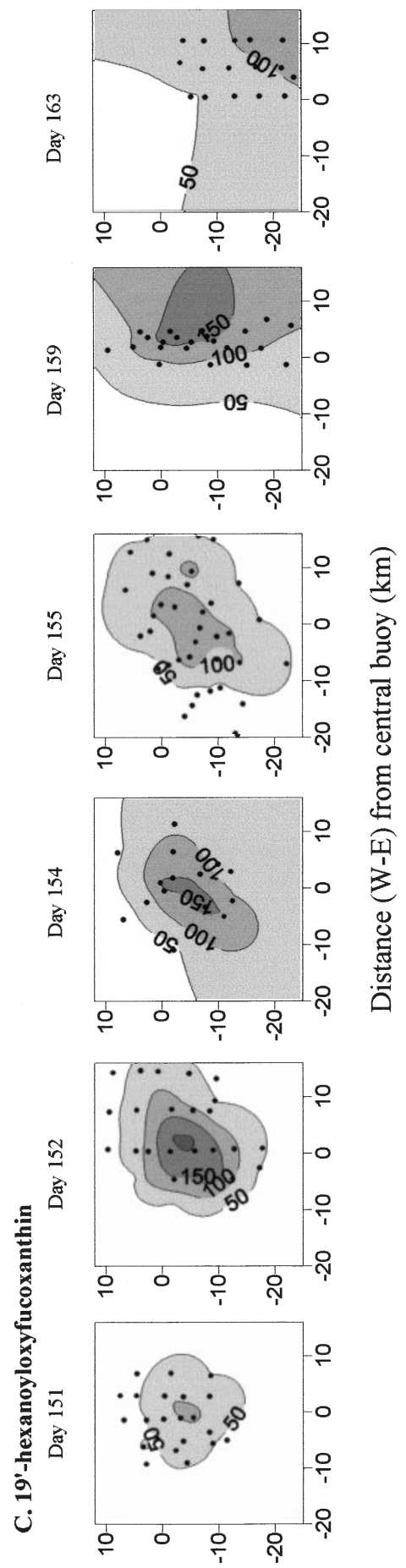

Distance (S-N) from central buoy $(\mathrm{km})$ 
sponding increase in microscopically estimated phytoplankton carbon biomass was about a factor of 4 over the same period. Both measures of phytoplankton community biomass remained at more-or-less constant levels ( 1600 ng chl $\mathrm{a}$ and $\left.120 \mu \mathrm{g} \mathrm{C}^{-1}\right)$ from JDs 155 to
158. Thus, in terms of net community response, phytoplankton chlorophyll and carbon increased markedly after the first and second iron additions. The third addition had virtually no effect on phytoplankton standing stocks in the patch.

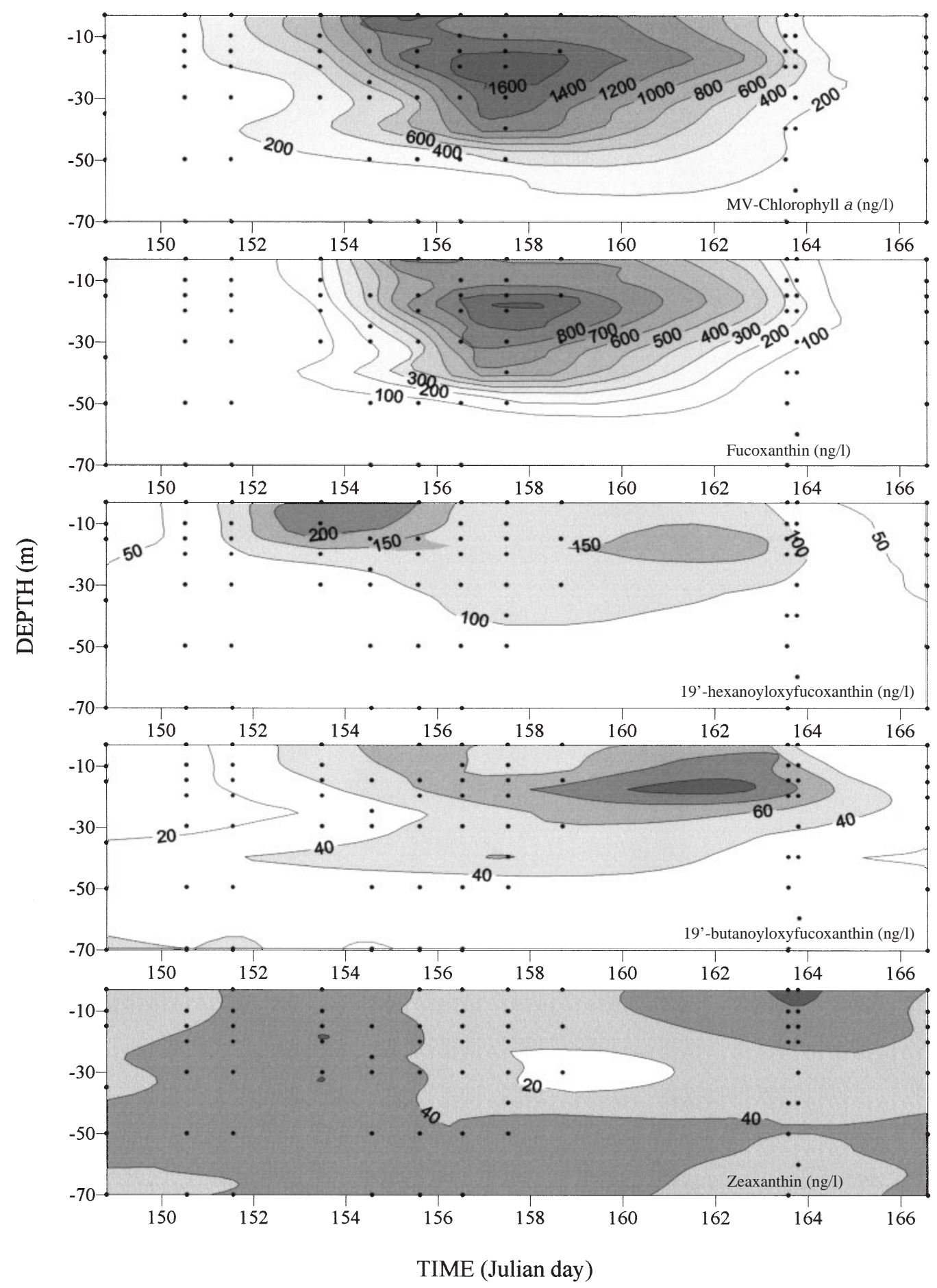

Fig. 2. Time-depth distributions of phytoplankton pigments in the iron-fertilized patch 


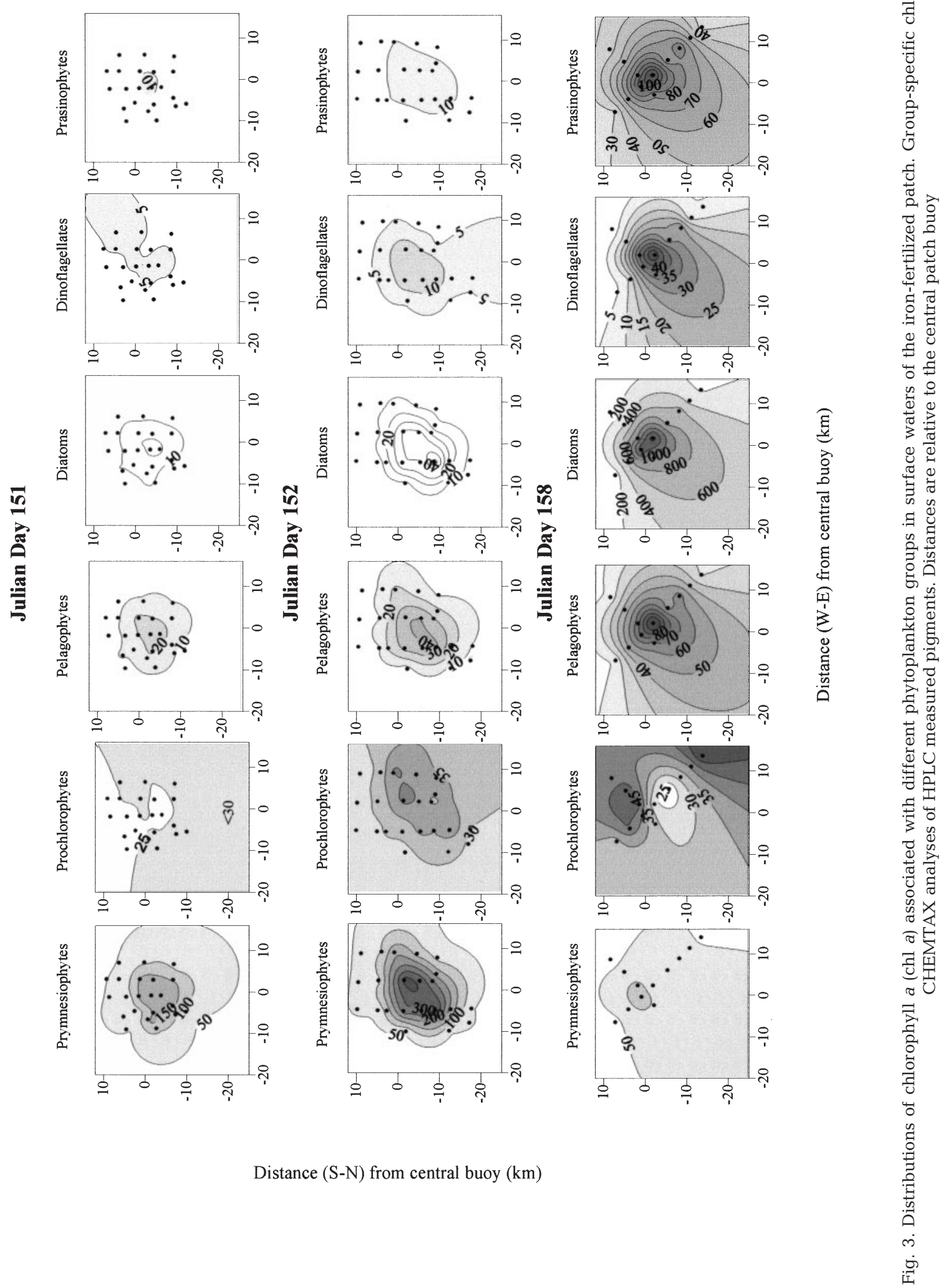



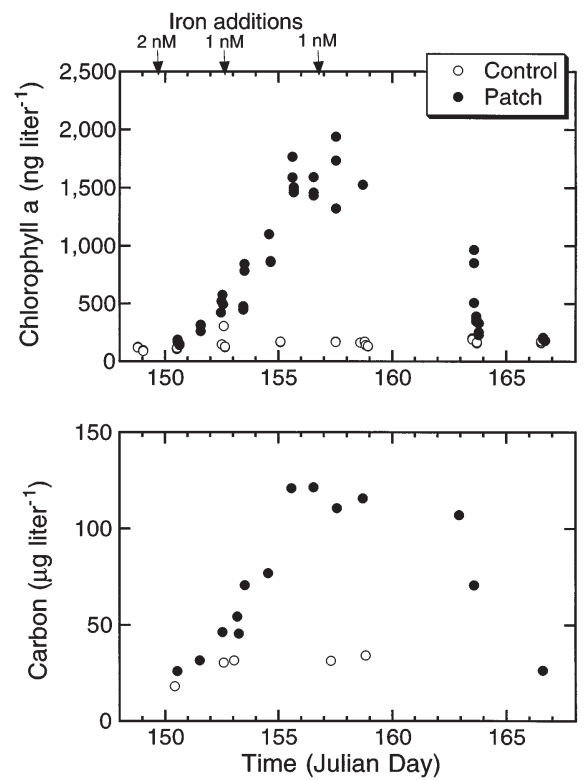

Fig. 4. Phytoplankton chl a and carbon biomass in the ironfertilized patch and in ambient 'control' seawater during the IronEx II experiment. All samples from $15 \mathrm{~m}$ depth

Pico-phytoplankton populations responded little to iron-enrichment (Fig. 5). Patch abundances of PRO were typically at or below the concentrations in contemporaneous control samples, and they fell somewhat below control estimates at the peak of the bloom (as shown more clearly in the detailed sampling of Cavender-Bares et al. 1999). Given the inferred increases in PRO cell size during the bloom, however, there was little difference between patch and control estimates of population biomass throughout the experiment. SYN abundances in the patch increased comparably to those in the ambient seawater, but the inferred increase in cell size from flowcytometric light scattering suggested a slight $(<2 \times)$ enhancement in SYN biomass between JDs 153 and 156 . Overall, the abundances and biomass of pico-eukaryotic phytoplankton (PEUK) in the patch were similar to or slightly below those at the control site.

Prymnesiophytes, the most abundant of the larger phytoplankton in the ambient community, showed a modest $(1.6 \times)$ increase in the patch between JDs 152 and 154. Their abundances were otherwise close to control levels
(Fig. 6). The response of dinoflagellates was similar $(1.4 \times$ increase). Diatoms differed from all other taxa in showing a clear and dramatic response to iron fertilization. Diatom abundances increased by a factor of 30 from initial estimates of 100 to 3000 cells ml-1 at the peak of the bloom. Diatom carbon estimates increased by about $100 \times$ to $>90 \mu \mathrm{g} \mathrm{C}^{-1}$ during the same time period. Whether large or small, all measured accumulations of phytoplankton cells in the patch are, of course, minimal estimates of the taxon's true response to iron-enrichment, since they do not include dilution due to the spatial expansion of the patch or other loss processes.

All categories of diatoms enumerated in microscopical analyses increased in absolute abundances and biomass in the iron enriched patch, but the increase was disproportionately greater for pennates (Table 1). Nitzschia bicapitata, the most abundant individual species in control waters, increased by less than a factor of 2 in the patch and decreased markedly in relative importance from 41 to $3 \%$ of diatom abundance and from 21 to $0.6 \%$ of biomass. Nonetheless, Nitzschia species dominated the bloom overall, accounting for $97 \%$ of diatom cell abundance and $70 \%$ of peak carbon biomass. Centric diatoms declined in relative importance in the patch, representing $38 \%$ of total diatom carbon in ambient waters but only $4 \%$ at the peak of the patch bloom.
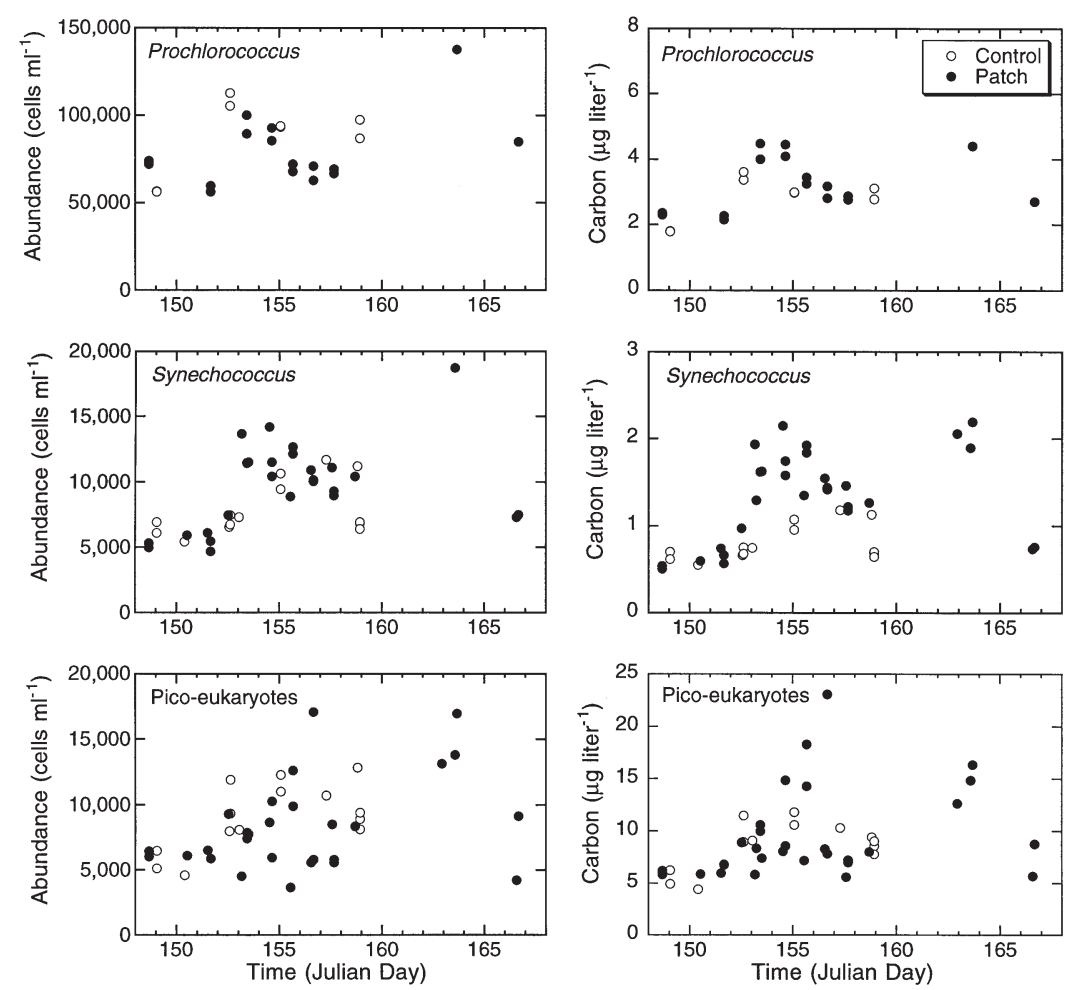

Fig. 5. Abundance and carbon biomass of picophytoplankton in patch and control waters during the IronEx II study 

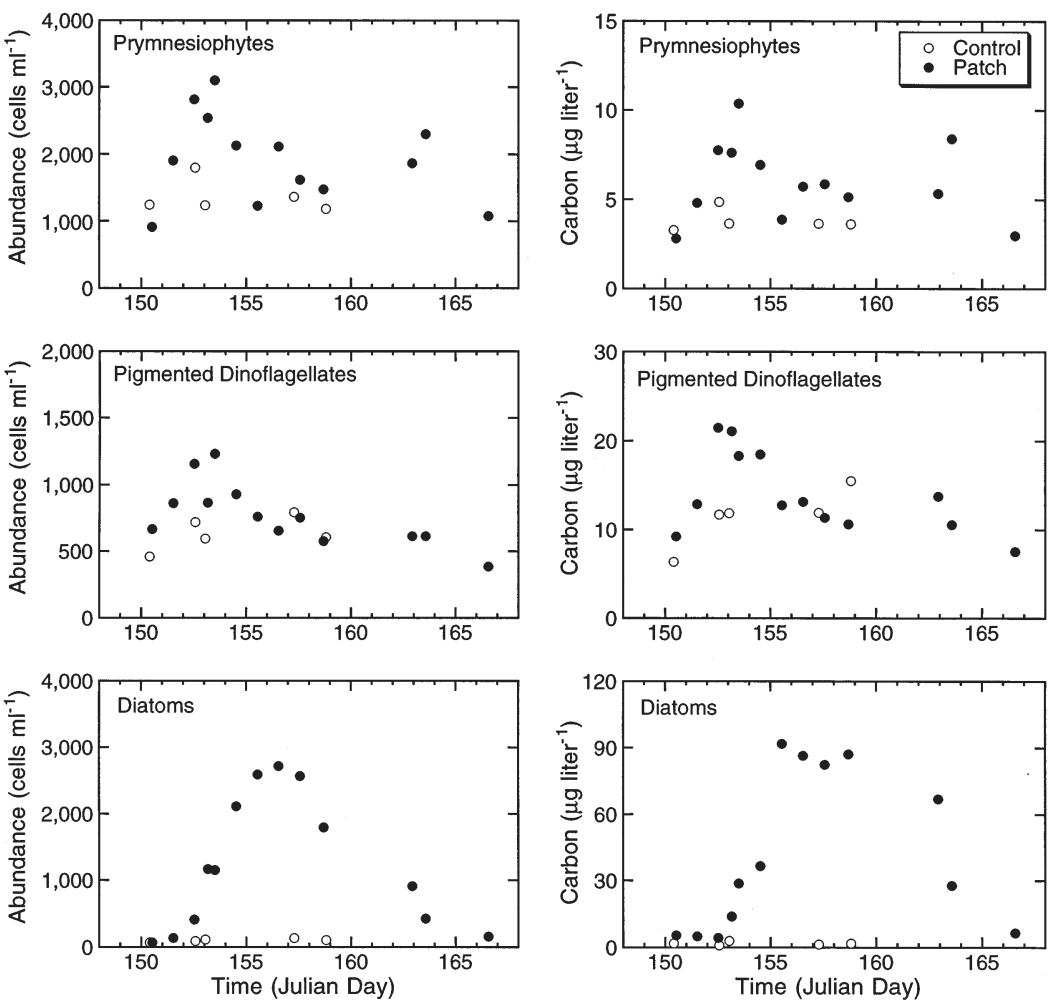

Fig. 6. Abundance and carbon biomass of prymnesiophytes, pigmented dinoflagellates and diatoms in patch and control waters during the IronEx II study

decreased from $>150$ at the start of the experiment to about 70 at the bloom peak. C:chl a of PRO was generally in the range of 70 to 80 , with little or no difference between patch and control water throughout the experiment. Diatom C:chl a declined to similar values during the patch bloom, and also apparently in some control samples. The C:chl a of prymnesiophytes varied from 65 to 85 in the ambient community and from 20 to 36 in the patch, with most of the difference having occurred before the first sampling (JD 150). Patch C:chl a estimates for cyanobacteria and dinoflagellates exhibited more gradual, but substantial, departures from control estimates over the course of the experiment. Dinoflagellate C:chl a was unrealistically high, dropping from an initial value of about 1500 to a low of 270 on JDs 155 and 156. In contrast to estimates for other taxa, the C:chl a ratio for SYN in the patch increased relative to initial and control ratios. This latter trend is the opposite to that indicated by cellular fluorescence from flow cytometric analyses (Fig. 9). While the fluorescence characteristics of PRO cells were

\section{Carbon:chlorophyll ratios}

The partitioning of chl a among the various phytoplankton groups with the CHEMTAX algorithm (Fig. 7) gives a somewhat different impression of net population changes compared to abundance and carbon biomass estimates (Figs. 5 \& 6). For instance, there appeared to be a substantial decrease in SYN chl a in the latter stages of the patch bloom, even though cell-abundances and biomass of SYN were similar to those in ambient waters. Pelagophytes were not enumerated in microscopical analyses, but pelagophyteassociated chl a from CHEMTAX increased markedly with the added iron. Among other eukaryotic taxa, prymnesiophytes and dinoflagellates showed substantially higher enhancement in taxon-specific chl a than noted for cell abundances. However, the dramatic increase in diatom-associated chl $a$ in the patch was consistent with abundance and carbon changes.

Fig. 8 shows carbon:chlorophyll ratios (C:chl $a, w: w)$ computed for all control and sampling stations where microscopical estimates of phytoplankton community carbon and CHEMTAX chlorophyll assessments were obtained from the same water bottles or closely spaced hydrocasts. The data suggest that community C:chl a entirely consistent with a slight patch increase in cell size with little difference between control and patch C:chl $a$, fluorescence emissions by SYN pigments (red $=$ chlorophyll, orange $=$ phycoerythrin $)$ showed

Table 1. Percentage composition of the diatom community in and out of the iron-fertilized patch. 'Control' estimates are the mean of 3 samplings of the ambient community; 'Patch' estimates are the mean of 4 samplings during peak concentrations in the fertilized patch (Julian Days 155 to 158)

\begin{tabular}{|lcccc|}
\hline Taxon & \multicolumn{5}{c|}{ Diatom } \\
& $\begin{array}{c}\text { Abundance }(\%) \\
\text { Control }\end{array}$ & $\begin{array}{c}\text { Carbon (\%) } \\
\text { Control }\end{array}$ & Patch \\
\hline Nitzschia bicapitata & 40.8 & 3.0 & 21.4 & 0.6 \\
Nitzschia spp. & 49.3 & 94.1 & 36.3 & 69.6 \\
Pseudonitzschia spp. & $<0.1$ & 0.4 & $<0.1$ & 2.5 \\
Tropidoneis/Haslea spp. & 0.6 & 0.1 & 4.0 & 17.2 \\
Thallasiothrix spp. & $<0.1$ & 0.6 & $<0.1$ & 3.2 \\
Other pennates & $<0.1$ & 0.4 & $<0.1$ & 2.5 \\
Total pennate diatoms & 90.6 & 98.6 & 61.7 & 95.6 \\
Chaetoceros spp. & 7.7 & 1.1 & 14.4 & 2.3 \\
Thalasiosira spp. & $<0.1$ & 0.1 & $<0.1$ & 0.7 \\
Other centrics & 1.7 & 0.1 & 23.9 & 1.4 \\
Total centric diatoms & 9.4 & 1.4 & 38.3 & 4.4 \\
\hline
\end{tabular}



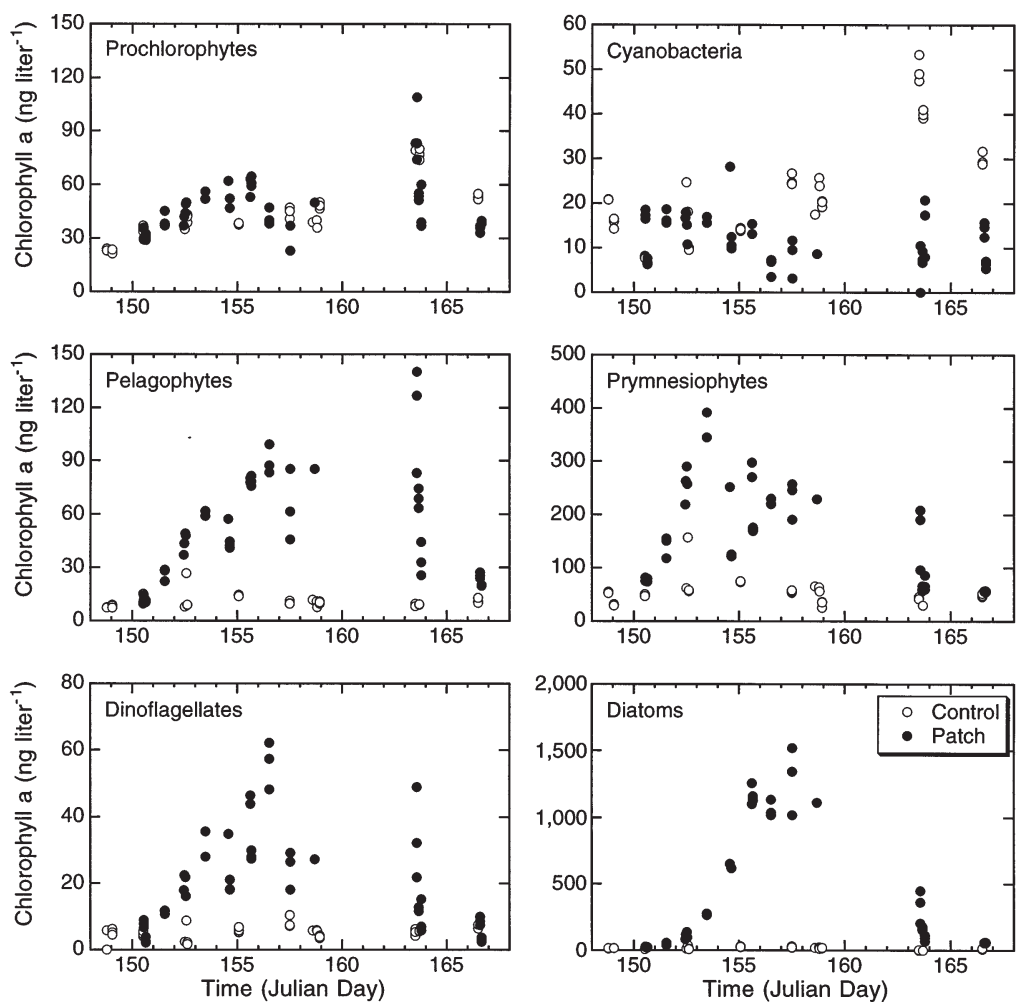

Fig. 7. Taxon-specific chl a associated with various phytoplankton groups in patch and control waters during the IronEx II study bloom. Dinoflagellate biomass was also enhanced about 2-fold in the patch, although there is some indication that the patch site contained higher concentrations of heterotrophic dinoflagellates initially.

Population abundances of heterotrophic bacteria were relatively constant in the ambient environment, varying only between 0.77 and $0.82 \times 10^{6}$ cells $\mathrm{ml}^{-1}$ from JDs 149 to 159 (Fig. 11). In contrast, there was a gradual, but significant bacterial increase in the iron-enriched patch. Cell abundances in the patch reached $1.3 \times$ $10^{6} \mathrm{ml}^{-1}$ by JD 157 . When the patch was revisited 6 d later (JD 163), bacterial den-

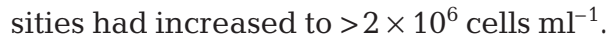
However, no evidence of enhanced bacterial concentrations was evident at the final sampling on JD 166.

\section{Community size structure}

Comparison of phytoplankton community size structure from filter-fractionated significant enhancement in the patch. These observations suggest that C:pigment ratios for SYN should have decreased for cellular carbon increases of $<3$-fold.

\section{Heterotrophic populations}

Nanoflagellates were numerical dominants in the ambient community of protistan grazers (Fig. 10). However, ciliates and non-pigmented dinoflagellates comprised about half of the biomass on average. Choanoflagellates appeared in low numbers in most samples, and cryptomonads were enumerated occasionally, but neither of these groups accounted for much of the protistan grazer biomass.

Within the variability of measurements, heterotrophic nanoflagellates showed little difference in or out of the patch, but a slight increasing trend is suggested from JDs 150 to 163 (Fig. 10). Ciliate abundance and carbon were about 3-fold higher in the patch than in the ambient environment during the peak of the
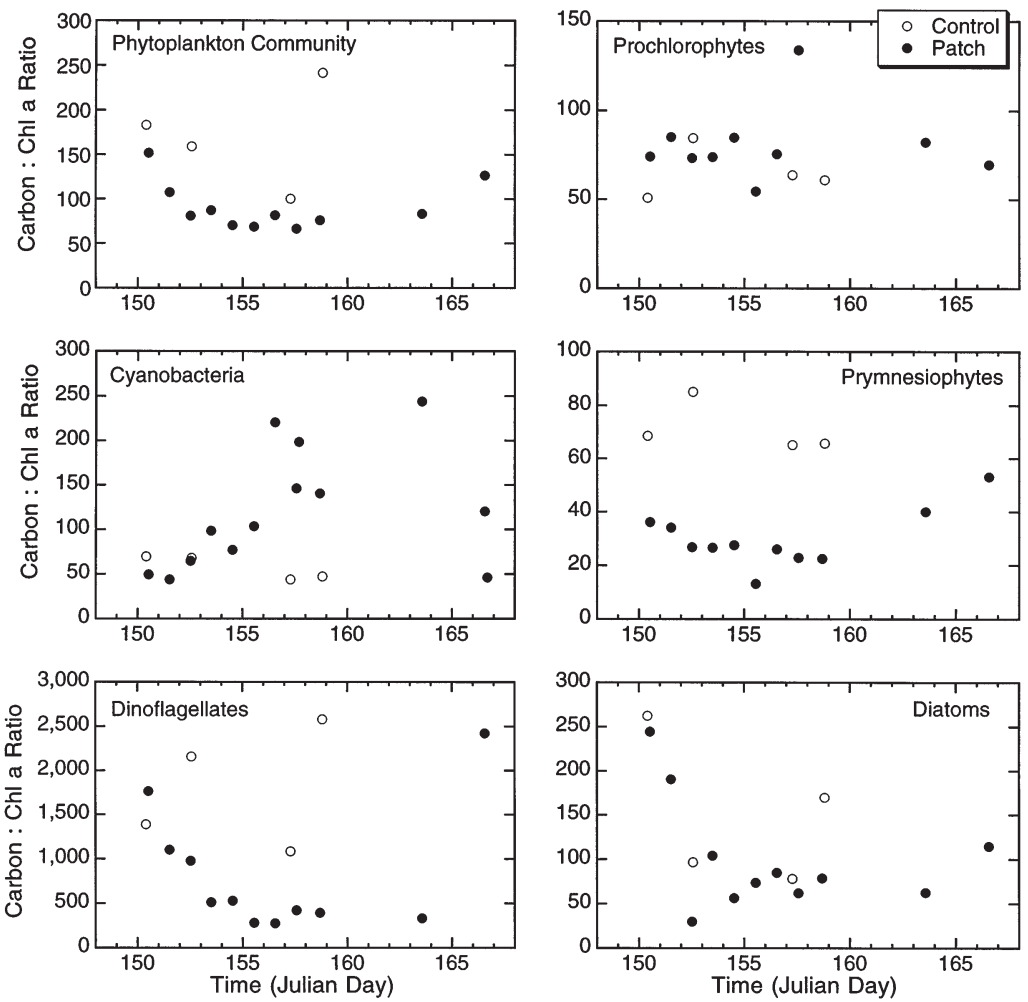

Fig. 8. Estimated C:chl a ratios in patch and control waters during the IronEx II study 


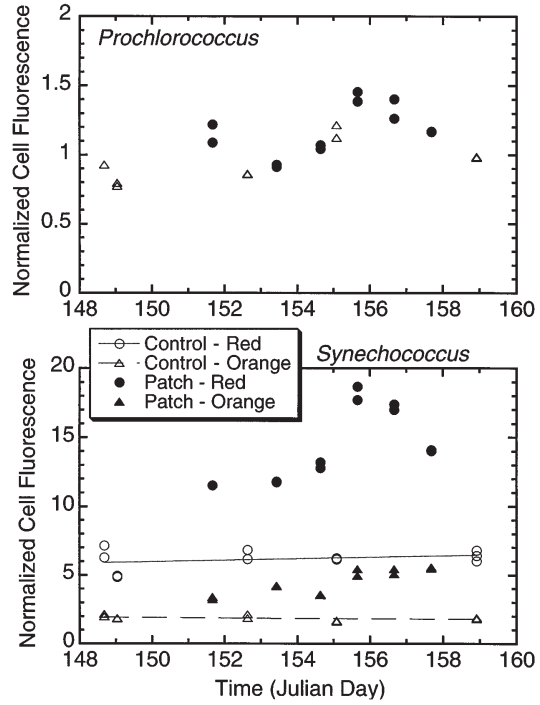

Fig. 9. Cellular fluorescence characteristics of PRO and SYN in patch and control waters during the IronEx II study. Cell fluorescence from flow cytometric analyses in arbitrary units relative to fluorescent microspheres patch) (Fig. 12). The major difference between patch and control assemblages occurred among cells $>20 \mu \mathrm{m}$ in length.

Among heterotrophic protists, the 2 to 5 and 5 to $10 \mu \mathrm{m}$ size categories also remained relatively unchanged in the patch (Fig. 13). Ciliates and dinoflagellates in each of the larger size categories were at least a factor of 2 higher in the patch at the peak of the bloom. In particular, the patch was marked by a significant assemblage of $>40 \mu \mathrm{m}$ protistan grazers.

\section{Net growth rates}

During the $5 \mathrm{~d}$ period of the IronEx II bloom increase (JDs 150 to 155), net growth rates of diatoms surpassed all other measured populations averaging $0.8 \mathrm{~d}^{-1}$ in terms of pigments and cell abundances and $0.62 \mathrm{~d}^{-1}$ as carbon biomass (Table 2). For relevant populations, the pigment data sets, with higher sampling density, typi- pigment samples and microscopical analyses give similar general conclusions $-<2 \mu \mathrm{m}$ cells were the most important size category in control waters while larger $(>18 \mu \mathrm{m})$ phytoplankton, particularly diatoms, dominated in the patch (Fig. 12). Due to unrealistically high estimates of dinoflagellate $\mathrm{C}: \mathrm{chl} a$ as noted above, the relative contributions of dinoflagellates to community biomass stand out as markedly different in terms of pigments and carbon. Also different in these comparisons is the strong influence of diatoms in all pigment size fractions in the patch. This difference is presumably a consequence of size sorting the microscopical cell counts according to cell length, while the relatively narrow pennate diatoms (or cell fragments and chloroplasts) might easily pass through the membrane filter pores in the pigment sizefractions. Microscopical carbon estimates from patch and control samples showed relatively little difference in biomass structure of phytoplankton size classes $<20 \mu \mathrm{m}$, and only modest differences in taxonomic composition (e.g. some Phaeocystis spp. and more diatoms in 5 to $20 \mu \mathrm{m}$ size fractions from the

Fig. 10. Abundance and carbon biomass of heterotrophic protists in patch and control waters during the IronEx II study
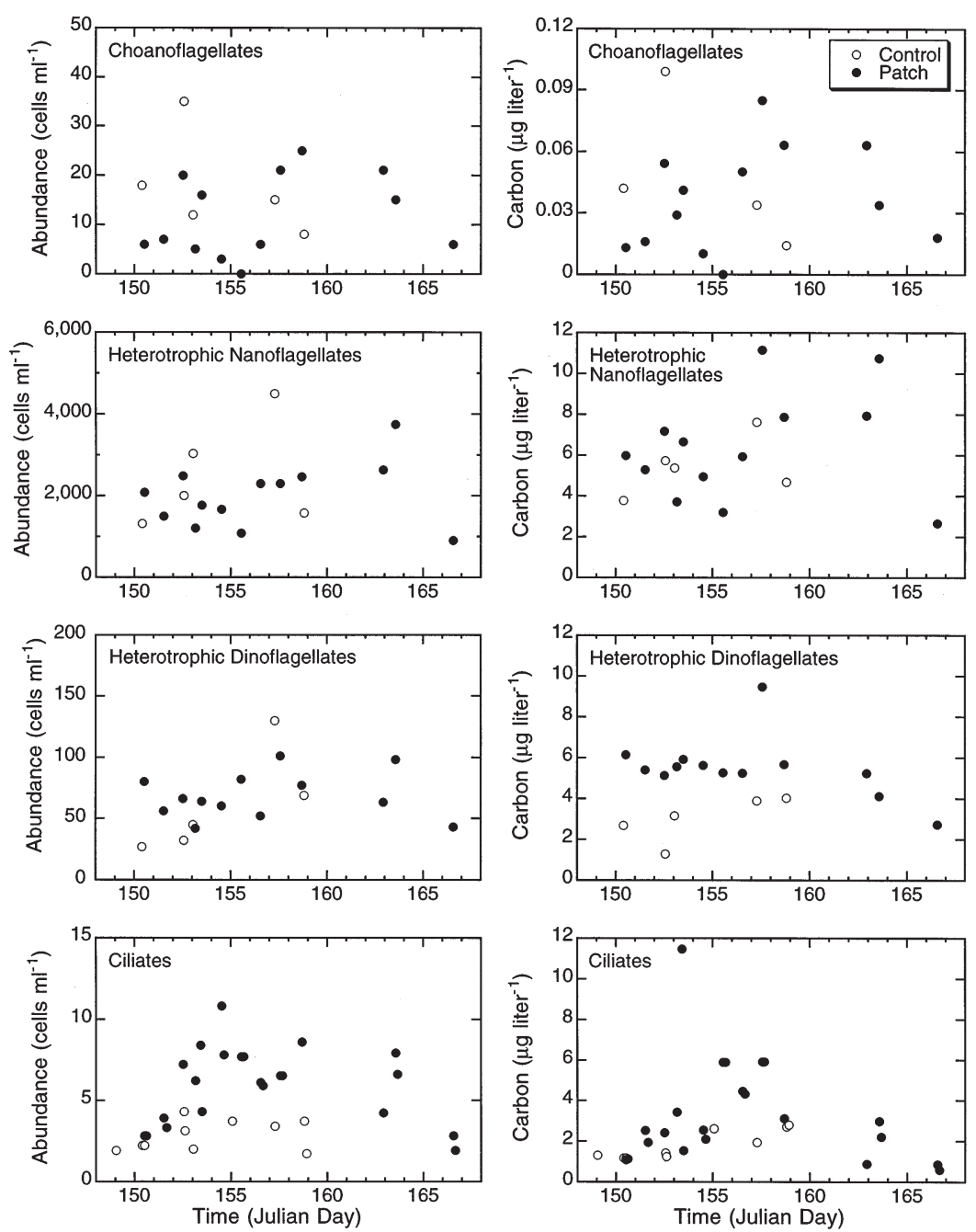


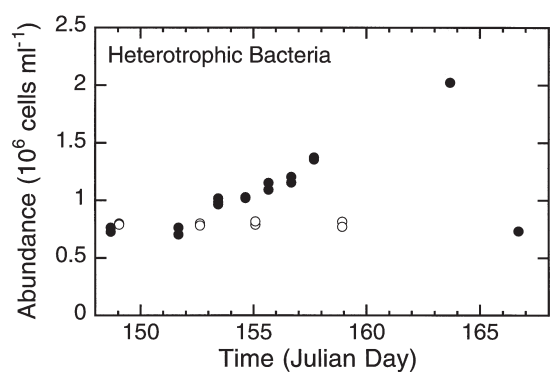

Fig. 11. Abundance of heterotrophic bacteria in patch (closed symbols) and control (open symbols) waters during the IronEx II study

cally gave higher rate estimates and narrower confidence intervals than corresponding biomass estimates (except for SYN). Among the autotrophs, only diatoms and total phytoplankton showed significantly positive net growth rates by all variables measured. Among the heterotrophs, only ciliates, bacteria and total heterotrophic biomass increased at statistically significant net rates. Unlike most other populations, which plateaued or declined after the peak bloom biomass on JD 155, bacteria continued to accumulate at a steady rate of $0.08 \mathrm{~d}^{-1}$ until JD 163. Over this extended time period heterotrophic nanoflagellates, which presumably feed on bacteria, also increased at a comparable rate.
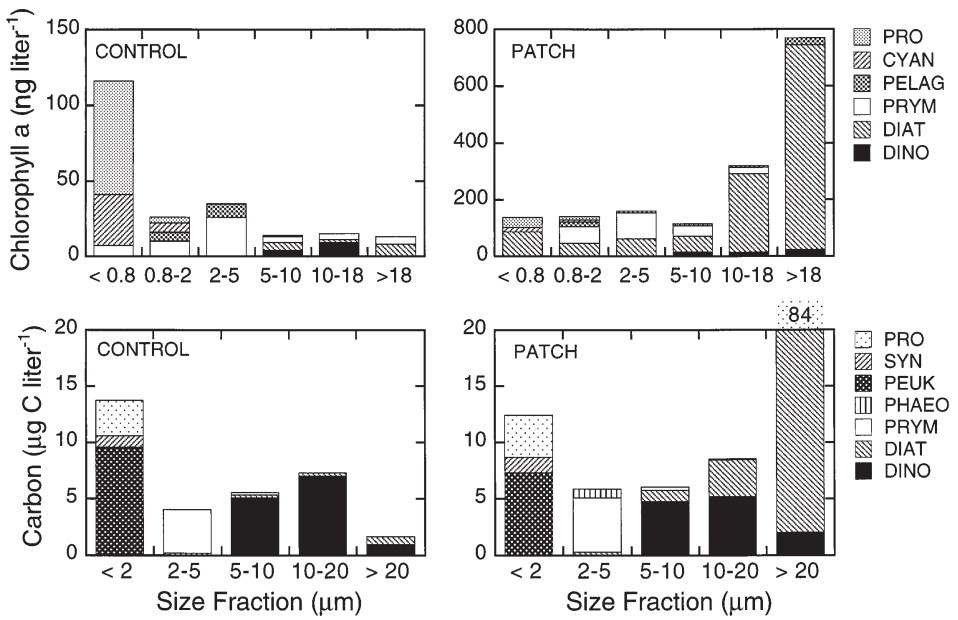

Fig. 12. Size-structure of the phytoplankton community in patch and control waters during the IronEx II study. Chl a size distributions are from filter fractioned samples on JD 163 (control) and JD 155 (patch). Carbon distributions are the means of 3 microscopically analyzed samples for controls (JDs 152, 157 and 158) and 4 patch samples from the peak of bloom biomass (JDs 155, 156, 157 and 158). PRO: Prochlorococcus spp., CYAN: cyanobacteria, PELAG: pelagophytes, PRYM: prymnesiophytes, DIAT: diatoms, DINO: dinoflagellates, SYN: Synechococcus spp., PEUK: pico-eukaryotes, and PHAEO: Phaeocystis spp.

\section{DISCUSSION}

\section{Possible deficiencies in the CHEMTAX algorithm}

Microscopical enumeration and pigment biomarkers have both been used extensively for assessing phytoplankton standing stocks in the oceans. Even so, when one considers uncertainties associated with pigmentbiomass ratios and biovolume-biomass conversions, neither is entirely reliable for assessing taxon-specific contributions to total community biomass. Methodological assumptions and uncertainties are particularly problematic under changing environmental conditions, such as the patch boom. Thus, it is reassuring that the inferences about community changes in the present study were in generally good agreement from both approaches. Our results do, however, bring into question possible problems with the CHEMTAX pigment algorithm that may be important when that is used as the main indicator of phytoplankton community structure in an open ocean system (e.g. MeyerHarms et al. 1999).

First, it seems unlikely that the cells counted as autotrophic dinoflagellates had natural C:chl a ratios of 1500 or more. When viewed under epifluorescence microscopy, such cells have a deep red fluorescence indicative of significant chlorophyll content. Bidigare \& Ondrusek (1996) and Andersen et al. (1996) have also observed that HPLC pigments underestimate the relative contribution of dinoflagellates compared to microscopical assessments. One possible explanation is that oceanic dinoflagellates and the coastal species used in the algorithm construction differ in accessory pigmentation. There are several distinct pigment types in the dinoflagellate group, including those dominated by peridinin, fucoxanthin or 19'hexanoyloxyfucoxanthin and those possessing phycobilipigments (Bjørnland \& LiaanJensen 1989). The dinoflagellate Gymnodinium breve, for example, lacks peridinin and possesses fucoxanthin-related carotenoids (Millie et al. 1993). Chavez et al. (1990) reported that most of the autotrophic dinoflagellates collected from equatorial waters were gymnodinoid in shape. Since it was not possible to distinguish peridinin and non-peridinin containing dinoflagellates from our microscopical counts, we cannot say conclusively that many or most lacked this assumed diagnostic pigment. Nonetheless, it seems likely that this was the case and that much of the chlorophyll residing in dinoflagellates was computationally assigned to other groups. 
Even if not numerically accurate, the patterns in dinoflagellate C:chl $a$ are somewhat satisfying in being consistent with the general declining trend for the phytoplankton community under iron-enrichment. In contrast, the CHEMTAX-based C:chl a trend for SYN (Fig. 8) was at odds with the independent assessment of cellular fluorescence from flow cytometry (Fig. 9). We attribute this discrepancy to SYN being a relatively minor component of the phytoplankton community and sharing an accessory pigment, zeaxanthin (ZEAX), with the more abundant PRO Consequently, small errors in the assignment of DV chl a:ZEAX to PRO can lead to large errors in the assignment of chl a to SYN in the CHEMTAX program.

We are also aware of a case where the application of the CHEMTAX algorithm to a pigment data set from the Southern Ocean suggested a large standing stock of PRO, which were not observed in contemporaneous FCM analyses (R. Letelier pers. com.). In this particular circumstance, direct assessment of DV chl a was unavailable, and the CHEMTAX algorithm was allowed to quantify PRO from other accessory pigments (chl $b$ and ZEAX). The obvious lesson from these examples is that a priori assumptions about the possible taxa present and their diagnostic properties strongly influence the results of the CHEMTAX algorithm. If this tool is to yield meaningful quantitative information on phytoplankton distributions in the oceans, we need to better understand how groupspecific pigment ratios vary with environmental conditions.
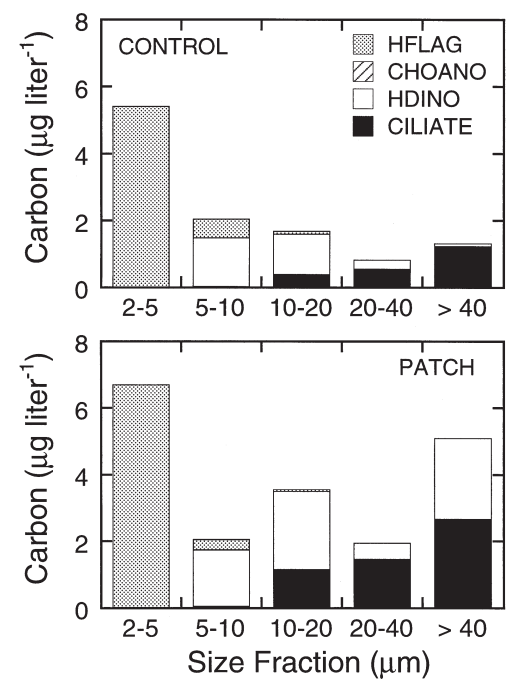

Fig. 13. Size-structure of the protistan grazer assemblage in patch and control waters during the IronEx II study. Control distributions are the means of 3 microscopically analyzed samples (JDs 152, 157 and 158). Patch distributions are the means of 4 sample analyses during the time of peak patch phytoplankton biomass (JDs 155, 156, 157 and 158)

\section{The IronEx II bloom}

Several complementary lines of evidence, including temporal and spatial evolution of phytoplankton pigment distributions, population abundances, biomass and community size composition, provide a relatively

Table 2. Net growth rate summary for autotrophic and heterotrophic populations during the IronEx II bloom. Pigments are from CHEMTAX analyses of group-specific chl a. Abundances and biomass are from flow cytometric or microscopical enumeration and carbon-biovolume conversions. Mean rate estimates are from least squares linear regressions of LN (standing stock) versus Time (Julian Day [JD]). All rates are for the period of fastest bloom response (JDs 150 to 155), unless otherwise noted. $95 \%$ confidence limits of mean rate estimates in parentheses

\begin{tabular}{|c|c|c|c|}
\hline Population & Pigment & $\begin{array}{l}\text { Net rate of increase }\left(\mathrm{d}^{-1}\right) \\
\text { Abundance }\end{array}$ & Biomass \\
\hline \multicolumn{4}{|c|}{ Autotrophic (pigmented) cells } \\
\hline Prochlorococcus & $0.12(0.10,0.15)$ & $0.05(-0.04,0.14)$ & $0.12(0.01,0.22)$ \\
\hline Synechococcus & $0.04(-0.18,0.14)$ & $0.17(0.09,0.25)$ & $0.24(0.15,0.33)$ \\
\hline Pico-eukaryotes & & $0.06(-0.05,0.17)$ & $0.15(0.06,0.24)$ \\
\hline Prymnesiophytes & $0.16(0.06,0.26)$ & $0.05(-0.21,0.32)$ & $0.09(-0.17,0.34)$ \\
\hline Pelagophytes & $0.34(0.27,0.41)$ & & \\
\hline Dinoflagellates & $0.36(0.25,0.47)$ & $0.02(-0.11,0.16)$ & $0.08(-0.10,0.26)$ \\
\hline Diatoms & $0.80(0.76,0.84)$ & $0.80(0.55,1.06)$ & $0.62(0.20,1.04)$ \\
\hline Total phytoplankton & $0.43(0.39,0.47)$ & & $0.30(0.24,0.37)$ \\
\hline \multicolumn{4}{|c|}{ Heterotrophic (nonpigmented) cells } \\
\hline Nanoflagellates & & $0.03(-0.06,0.12)$ & $0.05(-0.06,0.15)$ \\
\hline Choanoflagellates & & $0.07(-0.23,0.38)$ & $0.24(-0.11,0.59)$ \\
\hline Dinoflagellates & & $0.03(-0.04,0.11)$ & $0.02(-0.03,0.07)$ \\
\hline Ciliates & & $0.12(0.05,0.20)$ & $0.16(0.03,0.29)$ \\
\hline Total heterotrophs & & & $0.05(0.04,0.10)$ \\
\hline Heterotrophic bacteria & & $0.08(0.07,0.09)$ & \\
\hline HBACT (JD 153-163) & & $0.08(0.00,0.15)$ & \\
\hline HFLAG (JD 153-163) & & $0.08(0.03,0.14)$ & \\
\hline
\end{tabular}


coherent picture of the plankton community response to iron fertilization in the HNLC equatorial Pacific. The 'greening' (Barber 1992) of equatorial waters occurred as approximately equal parts of increased phytoplankton biomass and increased pigment content per unit biomass. The latter effect was broadly distributed among the eukaryotic algae. The former was strongly dominated by diatoms, which increased by about 70 -fold over a $6 \mathrm{~d}$ period, compared to typically less than 2-fold changes for other plankton groups. The diatom response was notable in being comprised largely of pennate forms, similar though somewhat larger than the dominant species in the ambient environment. Centric forms, typically the most important forms in coastal blooms, actually declined in relative importance. Among both autotrophic and heterotrophic protists, iron fertilization had little impact on the composition and biomass structure of $<10 \mu \mathrm{m}$ cells. However, some stimulation of the microbial loop pathway, either directly from iron addition (e.g. Barbeau et al. 1996, Tortell et al. 1996) or indirectly from enhanced availability of dissolved organic substrates, is evident in the gradual increases of HBACT and HFLAG bacterivores. The increasing abundance and biomass of large protistan consumers (heterotrophic dinoflagellates and ciliates) indicate additional food web responses.

Several control mechanisms must operate to explain all of the observations described above. First and foremost, the effects of iron are clearly demonstrated by the explosive increase in diatom abundance and biomass following fertilization. Prior to any biomass accumulation, however, the photochemical quantum efficiency of the phytoplankton photosystem II apparatus approximately doubled during the first $24 \mathrm{~h}$ after iron addition (Behrenfeld et al. 1996). The decreasing $\mathrm{C}: \mathrm{chl}$ a ratios in most phytoplankton groups were another likely cellular-level response to increased iron availability. Although centric diatoms were present in the background community in appreciable quantities ( $10 \%$ of diatom abundance and $38 \%$ of biomass), their surprising decrease in relative importance during the patch bloom suggests that not all taxa benefited equally from the added iron. The 'winners', larger versions of the long slender pennate cells that dominate the ambient community, must have enjoyed a competitive advantage over centric cells in iron uptake (high surface area:volume) and growth rates or suffered reduced losses due to zooplankton grazing and cell sinking. Among Nitzschia species, the shift to cells of larger size suggests selective grazing on the smaller forms, which are presumed to have an inherent advantage in nutrient uptake capability and reduced cell sinking. This would imply that protistan grazers, such as the larger ciliates and dinoflagellates that in- creased during the bloom, may have been significant consumers of diatoms.

The relative constancy of small size fractions during the patch bloom provides circumstantial evidence for closely balanced phytoplankton growth and loss processes at lower levels of the food web. Previous experimental studies have indicated that grazer regulation of small phytoplankton is a general feature of open ocean HNLC and oligotrophic regions (Landry et al. 1995, 1997, 1998, Calbet \& Landry 1999). The present results suggest that this control mechanism can be remarkably efficient even in the face of substantial environmental perturbation. What is not apparent from the present results, however, is the extent to which grazer regulation was 'tested' by increased growth rates of small phytoplankton taxa in the iron-enriched patch. The present evidence, including size increases of pico-phytoplankton inferred from flow cytometric analyses (Cavender-Bares et al. 1999) and enhanced cellular pigment levels in other taxa, implies some increase in growth rates.

At least partial escape of pennate diatoms from grazers and other loss processes is evident in their pronounced biomass accumulation in the iron-fertilized patch. Nonetheless, the leveling off of plankton stocks between JDs 155 and 159 could mean that grazing balance was reestablished after the first $6 \mathrm{~d}$ of net positive growth. The alternative explanation is that the bloom was attenuated by the depletion of an essential macroor micro-nutrient (e.g. N, P, Si, Fe, Zn). In this regard, we note that the extended period of peak bloom biomass began $2 \mathrm{~d}$ before the third and final iron addition. Microscopical observations during this time showed no indication of phytoplankton physiological stress, and C:chl a ratios remained low through the bloom plateau. More tellingly, Fast-Repetition-Rate fluorometer estimates of quantum efficiency remained 2-fold higher than the ambient community and comparable to measurements on Days 1 to 3 of the experiment (Behrenfeld et al. 1996). Nonetheless, there were some indications that iron may not have been sufficiently available for optimal phytoplankton growth (e.g. Erdner \& Anderson 1999), and macro-nutrients were depleted during the bloom from 10 to $6 \mu \mathrm{M}$ nitrate and from 5 to $1 \mu \mathrm{M}$ silicate. If micro- or macro-nutrients limited the patch bloom exclusively, we would expect to see evidence of this in sharply reduced phytoplankton growth rates during the stagnant biomass phase. On the other hand, if grazing balance was involved in the control of the bloom peak, we would expect high phytoplankton growth rates to continue through the bloom plateau, with essential nutrients returned to phytoplankton via an efficient remineralization loop (Landry et al. 1997), as well as advective and mixing processes. These issues are explored more thoroughly by Landry et al. (2000). 
In summary, the present study documents a substantial diatom bloom and a shift to larger autotrophic and heterotrophic microplankton in response to iron fertilization of HNLC equatorial waters. The temporal patterns in biomass and size-structure response suggest several ways in which grazing processes and/or nutrient limitation might be implicated in the regulation of phytoplankton stocks at the peak of the IronEx II patch bloom. In companion studies, we investigate the extent to which mesozooplankton populations respond to and contribute to grazing of the patch phytoplankton community (Rollwagen Bollens \& Landry 2000). Following that, we provide a dynamic interpretation of phytoplankton growth and microzooplankton grazing rate interactions during the IronEx II bloom (Landry et al. 2000).

Acknowledgements. The planning and implementation of the IronEx fertilization experiments required the efforts and logistical support of many. We gratefully acknowledge the inspiration of John Martin and the dedication of all those in the IronEx science team and RV 'Melville' crew who contributed to the success of this study. The present work was supported by US Office of Naval Research Grant N00014-941-0125 to KHC and by National Science Foundation Grants OCE-9022117 and -9218152 to MRL, -9022321 to RRB and -9217518 to KHC. Contributions No. 5238 from the School of Ocean and Earth Science and Technology, University of Hawai'i at Manoa, Honolulu, Hawai'i 96822, USA, and No. 559 from the US JGOFS Program.

\section{LITERATURE CITED}

Andersen RA, Bidigare RR, Keller MD, Latasa M (1996) A comparison of HPLC pigment signatures and electron microscopic observations for oligotrophic waters of the North Atlantic and Pacific Oceans. Deep-Sea Res II 43: $517-537$

Banse K (1990) Does iron really limit phytoplankton production in the offshore subarctic Pacific? Limnol Oceanogr 35: $772-775$

Banse K (1995) Community response to IRONEX. Nature 375: 112

Barbeau, K, Moffett JW, Caron DA, Croot PL, Erdner DL (1996) Role of protozoan grazing in relieving iron limitation of phytoplankton. Nature 380:61-64

Barber RT (1992) Introduction to the WEC88 cruise: an investigation into why the equator is not greener. J Geophys Res 97:609-610

Behrenfeld MJ, Bale AJ, Kolber ZS, Aiken J, Falkowski PG (1996) Confirmation of iron limitation of phytoplankton photosynthesis in the equatorial Pacific Ocean. Nature 383:508-511

Bidigare RR, Ondrusek ME (1996) Spatial and temporal variability of phytoplankton pigment distributions in the central equatorial Pacific Ocean. Deep-Sea Res II 43: 809-833

Bidigare RR, Hanson KL, Buesseler K, Wakeham SG, Freeman KH, Pancost RD, Millero FJ, Steinberg P, Popp BN, Latasa M, Landry MR, Laws EA (1999) Iron-stimulated changes in ${ }^{13} \mathrm{C}$ fractionation and export by equatorial
Pacific phytoplankton: toward a paleo-growth rate proxy Paleoceanogr 14:589-595

Bjørnland T, Liaaen-Jensen S (1989) Distribution of carotenoids in relation to chromophyte phylogen and systematics. In: Green JC, Leadbeater BSC, Diver WL (eds) The chromophyte algae: problems and perspectives. Oxford Science Press, Oxford, p 37-60

Børsheim KY, Bratbak G (1987) Cell volume to cell carbon conversion factors for a bacterivorous Monas sp. enriched from seawater. Mar Ecol Prog Ser 36:171-175

Calbet A, Landry MR (1999) Mesozooplankton influences on the microbial food web: direct and indirect trophic interactions in the oligotrophic open-ocean. Limnol Oceanogr 44:1370-1380

Cavender-Bares KK, Mann EL, Chisholm SW, Ondrusek ME, Bidigare RR (1999) Differential response of equatorial Pacific phytoplankton to iron fertilization. Limnol Oceanogr 44:237-246

Chavez FP, Buck KR, Barber RT (1990) Phytoplankton taxa in relation to primary production in the equatorial Pacific. Deep-Sea Res 37:1733-1752

Chavez FP, Buck KR, Coale KH, Martin JH, DiTullio GR, Welschmeyer NA (1991) Growth rates, grazing, sinking, and iron limitation of equatorial Pacific phytoplankton. Limnol Oceanogr 36:1816-1833

Coale KH, Johnson KS, Fitzwater SE, Gordon RM, Tanner S Chavez FP, Ferioli L, Sakamoto C, Rogers P, Millero F, Steinberg $\mathrm{P}$, Nightingale $\mathrm{P}$, Cooper $\mathrm{D}$, Cochlan WP, Landry MR, Constantinou J, Rollwagen G, Trasvina A Kudela R (1996) A massive phytoplankton bloom induced by an ecosystem-scale iron fertilization experiment in the equatorial Pacific Ocean. Nature 383:495-501

Cooper DJ, Watson AJ, Nightingale RD (1996) Large decrease in ocean-surface $\mathrm{CO}_{2}$ fugacity in response to in situ iron fertilization. Nature 383:511-513

Cullen JJ (1991) Hypotheses to explain high-nutrient conditions in the open sea. Limnol Oceanogr 40:1336-1343

Cullen JJ (1995) Status of the iron hypothesis after the OpenOcean Enrichment Experiment. Limnol Oceanogr 40: $1336-1343$

Erdner DL, Anderson DM (1999) Ferredoxin and flavodoxin as biochemical indicators if iron limitation during openocean iron-enrichments. Limnol Oceanogr 44:1609-1615

Goericke R, Repeta DJ (1993) Chlorophylls $a$ and $b$ and divinyl chlorophylls $a$ and $b$ in the open subtropical North Atlantic Ocean. Mar Ecol Prog Ser 101:307-313

Greene RM, Kolber ZS, Swift DG, Tindale NW, Falkowski PG (1994) Physiological limitation of phytoplankton photosynthesis in the Eastern Equatorial Pacific determined from variability of the quantum yield of fluorescence. Limnol Oceanogr 39:1061-1074

Kolber ZS, Barber RT, Coale KH, Fitzwater SE, Greene RM, Johnson KS, Lindley S, Falkowski PG (1994) Iron limitation of phytoplankton photosynthesis in the equatorial Pacific Ocean. Nature 731:145-149

Landry MR, Constantinou J, Kirshtein J (1995) Microzooplankton grazing in the central equatorial Pacific during February and August 1992. Deep-Sea Res II 42:657-671

Landry MR, Kirshtein J, Constantinou J (1996) Abundances and distributions of picoplankton populations in the central equatorial Pacific from $12^{\circ} \mathrm{N}$ to $12^{\circ} \mathrm{S}, 140^{\circ} \mathrm{W}$. DeepSea Res II 43:871-890

Landry MR, Barber RT, Bidigare RR, Chai F, Coale KH, Dam HG, Lewis MR, Lindley ST, McCarthy JJ, Roman MR, Stoecker DK, Verity PG, White JR (1997) Iron and grazing constraints on primary production in the central equatorial Pacific: an EqPac synthesis. Limnol Oceanogr 42:405-418 
Landry MR, Brown SL, Campbell L, Constantinou J, Liu H (1998) Spatial patterns in phytoplankton growth and microzooplankton grazing in the Arabian Sea during monsoon forcing. Deep-Sea Res II 45:2353-2368

Landry MR, Constantinou J, Latasa M, Brown SL, Bidigare RR, Ondrusek ME (2000) Biological response to iron fertilization in the eastern equatorial Pacific (IronEx II). III. Dynamics of phytoplankton growth and microzooplankton grazing. Mar Ecol Prog Ser 201:57-72

Latasa M, Bidigare RR, Ondrusek ME, Kennicutt II MC (1996) HPLC analysis of algal pigments: a comparison exercise among laboratories and recommendations for improved analytical performance. Mar Chem 51:3115-3124

Lessard E (1991) The trophic role of heterotrophic dinoflagellates in diverse marine environments. Mar Microb Food Webs 5:49-58

Mackey MD, Mackey DJ, Higgins HW, Wright SW (1996) CHEMTAX - a program for estimating class abundances from chemical markers: application to HPLC measurements of phytoplankton. Mar Ecol Prog Ser 144:265-283

Mackey MD, Mackey DJ, Higgins HW, Wright SW (1997) CHEMTAX users manual: a program for estimating class abundances form chemical markers application to HPLC measurements of phytoplankton pigments. National Library of Australia

Martin JH (1990) Glacial-interglacial $\mathrm{CO}_{2}$ change: the iron hypothesis. Paleoceanography 5:1-13

Martin JH, Gordon RM, Fitzwater SE (1991) The case for iron. Limnol Oceanogr 36:1793-1802

Martin JH, Coale KH, Johnson KS, Fitzwater SE, Gordon RM, Tanner SJ, Hunter CN, Elrod VA, Nowicki JL, Coley TL, Barber RT, Lindley S, Watson AJ, Van Scoy K, Law CS, Liddicoat MI, Ling R, Stanton T, Stockel J, Collins C, Anderson A, Bidigare R, Ondrusek M, Latasa M, Millero FJ, Lee J, Yao W, Zhang JZ, Friederich G, Sakamoto C, Chavez F, Buck K, Kolber Z, Greene R, Falkowski P, Chisholm SW, Hoge F, Swift R, Yungel J, Turner S, Nightingale P, Hatton A, Liss P, Tindale NW (1994) Testing the iron hypothesis in ecosystems of the equatorial Pacific Ocean. Nature 371:123-129

Meyer-Harms B, Irigoien X, Head R, Harris R (1999) Selective-feeding on natural phytoplankton by Calanus finmarchicus before, during, and after the 1997 spring bloom in the Norwegian Sea. Limnol Oceanogr 44:154-165

Millie DF, Paerl HW, Hurley JP (1993) Microalgal pigment assessments using high-performance liquid chromatogra-

Editorial responsibility: Otto Kinne (Editor),

Oldendorf/Luhe, Germany phy: a synopsis of organismal and ecological applications. Can J Fish Aquat Sci 50:2513-2526

Monger BC, Landry MR (1993) Flow cytometric analysis of marine bacteria with Hoechst 33342. Appl Environ Microbiol 59:905-911

Putt M, Stoecker DK (1989) An experimentally determined carbon:volume ratio for marine 'oligotrichous' ciliates from estuaries and coastal waters. Limnol Oceanogr 34: 1097-1103

Rollwagen Bollens GC, Landry MR (2000) Biological response to iron fertilization in the eastern equatorial Pacific (IronEx II). II. Mesozooplankton abundance, biomass, depth distribution and grazing. Mar Ecol Prog Ser 201: 43-56

Shalapyonok A, Olson RJ, Shalapyonok LS (in press) Arabian Sea phytoplankton during the Southwest and Northeast Monsoons 1995: composition, size structure, and biomass from individual cell properties measured by flow cytometry. Deep-Sea Res II

Silver MW, Gowing MM (1991) 'Particle' flux: Origins and biological components. Prog Oceanogr 26:75-113

Strathmann RR (1967) Estimating the organic carbon content of phytoplankton from cell volume or plasma volume. Limnol Oceanogr 12:411-418

Tortell PD, Maldonado MT, Price NM (1996) The role of heterotrophic bacteria in iron-limited ocean ecosystems. Nature 383:330-332

Turner SM, Nightingale PD, Spokes LJ, Liddicoat MI, Liss PS (1996) Increased dimethyl sulphide concentration in sea water from in situ enrichment. Nature 383:513-517

Vaulot D (1989) CYTOPC: processing software for flow cytometric data. Signal to Noise 2:8

Vaulot D, Courties C, Partensky F (1989) A simple method to preserve phytoplankton for flow cytometric analyses. Cytometry 10:629-635

Verity PG, Robertsen CY, Tronzo CR, Andrews MG, Nelson JR, Sieracki ME (1992) Relationships between cell volume and the carbon and nitrogen content of marine photosynthetic nanoplankton. Limnol Oceanogr 37:1434-1446

Verity PG, Stoecker DK, Sieracki ME, Nelson JR (1996) Microzooplankton grazing of primary production in the equatorial Pacific. Deep-Sea Res II 43:1227-1255

Watson AJ, Laws CS, Van Scoy KA, Millero FJ, Yao W, Friederich GE, Liddicoat MI, Wanninkof RH, Barber RT, Coale KH (1994) Minimal effect of iron fertilization on seasurface carbon dioxide concentrations. Nature 371:143-145

Submitted: July 7, 1999; Accepted: December 15, 1999

Proofs received from author(s): July 12, 2000 